\title{
Reviews and syntheses: Impacts of plant-silica-herbivore interactions on terrestrial biogeochemical cycling
}

\author{
Bernice C. Hwang ${ }^{1}$ and Daniel B. Metcalfe ${ }^{1,2}$ \\ ${ }^{1}$ Department of Physical Geography and Ecosystem Science, Lund University, Sölvegaten 12, Lund, 223 62, Sweden \\ ${ }^{2}$ Department of Ecology and Environmental Science, Umeå University, Linnaeus väg 6, Umeå, 901 87, Sweden
}

Correspondence: Bernice C. Hwang (bernice.hwang@ @ateko.lu.se)

Received: 27 October 2020 - Discussion started: 5 November 2020

Revised: 18 December 2020 - Accepted: 3 January 2021 - Published: 17 February 2021

\begin{abstract}
Researchers have known for decades that silicon plays a major role in biogeochemical and plant-soil processes in terrestrial systems. Meanwhile, plant biologists continue to uncover a growing list of benefits derived from silicon to combat abiotic and biotic stresses, such as defense against herbivory. Yet despite growing recognition of herbivores as important ecosystem engineers, many major gaps remain in our understanding of how silicon and herbivory interact to shape biogeochemical processes, particularly in natural systems. We review and synthesize 119 available studies directly investigating silicon and herbivory to summarize key trends and highlight research gaps and opportunities. Categorizing studies by multiple ecosystem, plant, and herbivore characteristics, we find substantial evidence for a wide variety of important interactions between plant silicon and herbivory but highlight the need for more research particularly in non-graminoid-dominated vegetation outside of the temperate biome as well as on the potential effects of herbivory on silicon cycling. Continuing to overlook silicon-herbivory dynamics in natural ecosystems limits our understanding of potentially critical animal-plant-soil feedbacks necessary to inform land management decisions and to refine global models of environmental change.
\end{abstract}

\section{Introduction}

For centuries researchers have intensively studied cycles of key nutrients influencing plant growth and diversity such as nitrogen $(\mathrm{N})$ and phosphorus $(\mathrm{P})$ across a diverse range of ecosystems (e.g., Elser et al., 2007). Meanwhile, studies have often overlooked other nutrients such as silicon $(\mathrm{Si})$, which is important for plant function and protection (Cooke et al., 2016) as well as for biogeochemical cycling (Street-Perrott and Barker, 2008). For instance, Si can reduce the impact of many abiotic and biotic pressures, including water, temperature and salinity stress, as well as nutrient deficiency, heavy metal toxicity, disease, and herbivory (Debona et al., 2017). Plants can likewise affect terrestrial silica fluxes by controlling weathering rates and activity of dissolved $\mathrm{Si}$ in soils and streams (Derry et al., 2005). Plants and their associated microbiota can accelerate the weathering of silicate minerals by altering the physical properties and reactivity of the soil environment (e.g., $\mathrm{pH}$, moisture, exposed surface area of minerals), and by taking up essential nutrients, which destabilizes silicate minerals (Drever, 1994; Street-Perrott and Barker, 2008, and references therein). Since the silicate weathering process consumes carbon dioxide $\left(\mathrm{CO}_{2}\right)$ through chemical weathering of calcium- and magnesium-silicate minerals in continental rocks, the effects of plants on the Si cycle may influence the global carbon (C) cycle (Street-Perrott and Barker, 2008).

Plants take up dissolved Si from direct weathering of mineral silicates and biogenic $\mathrm{Si}$ released from leaf litter to soil (Cornelis and Delvaux, 2016), and Si in plants exceeds the concentrations of many plant macro-nutrients (Epstein, 1999). Si accumulation varies among species, with some plants containing only trace amounts, whereas Si can constitute up to $10 \%$ plant dry mass in "high Si accumulators" such as many grasses (Hodson et al., 2005). In the last decade, many studies have focused on agricultural systems (Guntzer et al., 2012; see also Fig. 1), in particular looking at grass species (e.g., McNaughton et al., 1985; Hartley and DeGabriel, 2016), with fewer studies examin- 
ing the role or importance of plant $\mathrm{Si}$ in natural (i.e., nonagricultural and in the field) environments even though the degree of dissolved Si passing through ecosystems as filters can vary dramatically by biome (Cooke and Leishman, 2011; Schoelynck et al., 2014; Cornelis and Delvaux, 2016; see also Fig. 1). In natural systems, studies have focused on graminoid-dominated vegetation types in the temperate biome, with relatively little research in tropical and boreal/subarctic forest and herbaceous vegetation types, even though plant Si uptake and storage in these systems may be significant (Cornelis et al., 2010; Katz, 2014).

Herbivory also creates a number of important feedbacks between plants and soils (Bardgett and Wardle, 2003). For example, invertebrate herbivores can supply a remarkably large amount of nutrients to tropical and subarctic systems compared to other major sources, bringing likely labile nutrients to the forest floor in the form of frass and bodies (Hartley and Jones, 2004; Metcalfe et al., 2014; Kristensen et al., 2018). Selective herbivory may also result in the dominance of plants that are nutrient poor and/or better defended, which ultimately produces more recalcitrant litter that decomposes more slowly (Bardgett and Wardle, 2003). Since plant Si is involved in plant defense (Debona et al., 2017), interactions between herbivory and plant Si (Massey et al., 2007) may have the potential to exert a powerful influence over ecosystem biogeochemistry and function.

There are multiple detailed reviews covering Si terrestrial biogeochemistry (e.g., Conley, 2002; Struyf and Conley, 2012) as well as Si-derived benefits to plants such as herbivore defense (e.g., Frew et al., 2018; Katz, 2019). However, given the likely importance of $\mathrm{Si}$ in multiple terrestrial biomes and the strong evidence for a tight coupling between plant $\mathrm{Si}$ and herbivory, remarkably few studies have investigated $\mathrm{Si}$-herbivory dynamics in the context of biogeochemical cycling. Here, we review the role of plant $\mathrm{Si}$-herbivore dynamics in biogeochemical cycles in order to summarize existing knowledge and emerging patterns, identify gaps in knowledge, and describe future research priorities. Towards this effort, we surveyed available literature between 1900 2020 in the Web of Science core collection database using search terms "silic" and "herbivor" and not "in silico" (314 results). We then filtered the results until only those publications that directly studied Si and herbivory remained (119 publications), which we categorized into various ecosystem, plant, and herbivore characteristics (Fig. 1). Our purpose is to identify areas where this knowledge can be currently useful, such as agricultural and land management, and assist efforts to better integrate potentially important but overlooked herbivore-plant-soil interactions into global biogeochemical models to more accurately predict ecosystem function shifts in the face of environmental change (Van der Putten et al., 2013).

\section{Silicon in terrestrial systems}

The biogeochemical Si cycle impacts global $\mathrm{CO}_{2}$ concentrations through weathering silicate minerals and transferring $\mathrm{CO}_{2}$ from the atmosphere to the lithosphere (Conley, 2002). In terrestrial systems, soil is the primary source of plant $\mathrm{Si}$, with global variability of soil-forming factors (e.g., parent rock, climate, topography, age, biota) explaining the large variability in Si cycling rates (Cornelis and Delvaux, 2016). Many plant species accumulate Si predominantly in leaves and needles as amorphous, biogenic silica, in large discrete bodies known as phytoliths. Si then returns to the soil when plant material decomposes either as dissolved $\mathrm{Si}$, a quickly available source of Si for terrestrial plants, or remains as phytoliths. Carbon incorporated by phytoliths may accumulate in soils and sediments for hundreds to thousands of years. For this reason, phytolith accumulation is considered as a key mechanism of biogeochemical C sequestration (Parr and Sullivan, 2005). Plant-accumulated Si has been shown to reduce the magnitude of Si released from terrestrial to aquatic ecosystems, thereby having direct implications on $\mathrm{Si}$ availability in rivers and coastal waters, which could influence diatom blooms and C uptake rates (Conley et al., 2008; Carey and Fulweiler, 2012; see also Fig. 3b). Ultimately, terrestrial systems supply approximately $78 \%$ of annual silica inputs to oceans (Tréguer and De La Rocha, 2013) and Siaccumulating vegetation accounts for $55 \%$ of terrestrial net primary productivity $\left(33 \mathrm{GtC} \mathrm{yr}^{-1}\right)$, on par with the rate that marine diatoms sequester C (Conley, 2002; Carey and Fulweiler, 2012).

Plants may preferentially use $\mathrm{Si}$ for certain functions such as structure and defense instead of C (Cooke and Leishman, 2012) as Si can provide plants with structural support at a lower metabolic cost than C (Raven, 1983). In some cases, $\mathrm{Si}$ is negatively correlated with lignin and cellulose content, possibly contributing to plant structural support, and phenol content (Schoelynck et al., 2010; Cooke and Leishman, 2012). Intermediate Si fertilization additions, for example, have enhanced aboveground growth for crops and reeds, possibly due to a partial substitution of organic $\mathrm{C}$ compounds by Si in plant tissue (Schaller et al., 2012; Neu et al., 2017).

Soil Si may also facilitate the acquisition and release of other essential plant nutrients. For example, a laboratory experiment demonstrated that $\mathrm{Si}$ addition significantly increased $\mathrm{P}$ mobilization in a variety of arctic soils (Schaller et al., 2019). Researchers have found that Si can also increase plant $\mathrm{N}$ use efficiency while decreasing $\mathrm{C}$ and increasing $\mathrm{P}$ in grasslands (Neu et al., 2017) and affect the calcium (Ca) content of grasses (Brackhage et al., 2013). The abundance of certain plant functional groups (e.g., Si-rich grasses) in plant communities can affect $\mathrm{Si}$ and Ca biogeochemistry as a result of differences in elemental concentrations among plant species and related effects on nutrient cycling via processes such as decomposition (Schaller et al., 2016). The potential of Si to affect plant growth and elemental stoichiometry in 
(a)

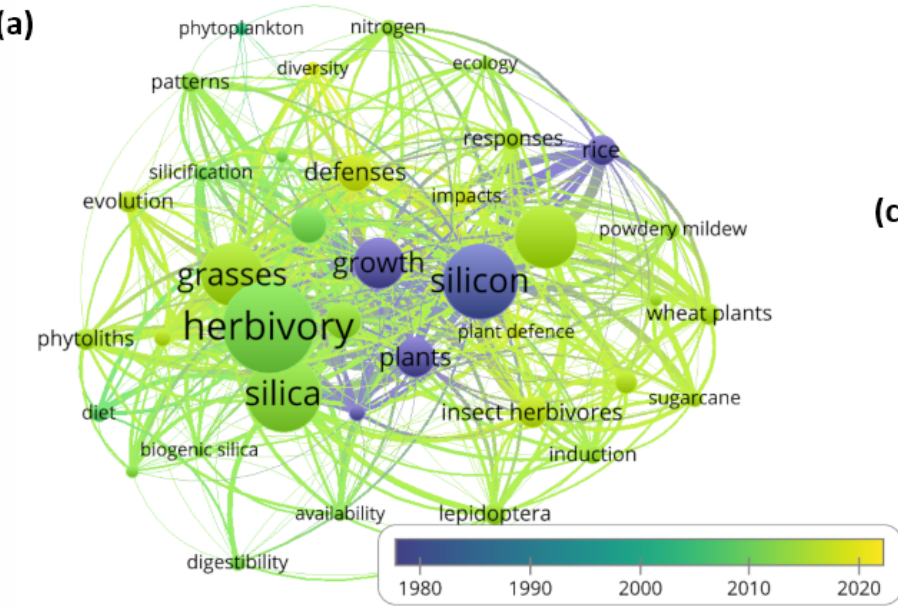

(b)
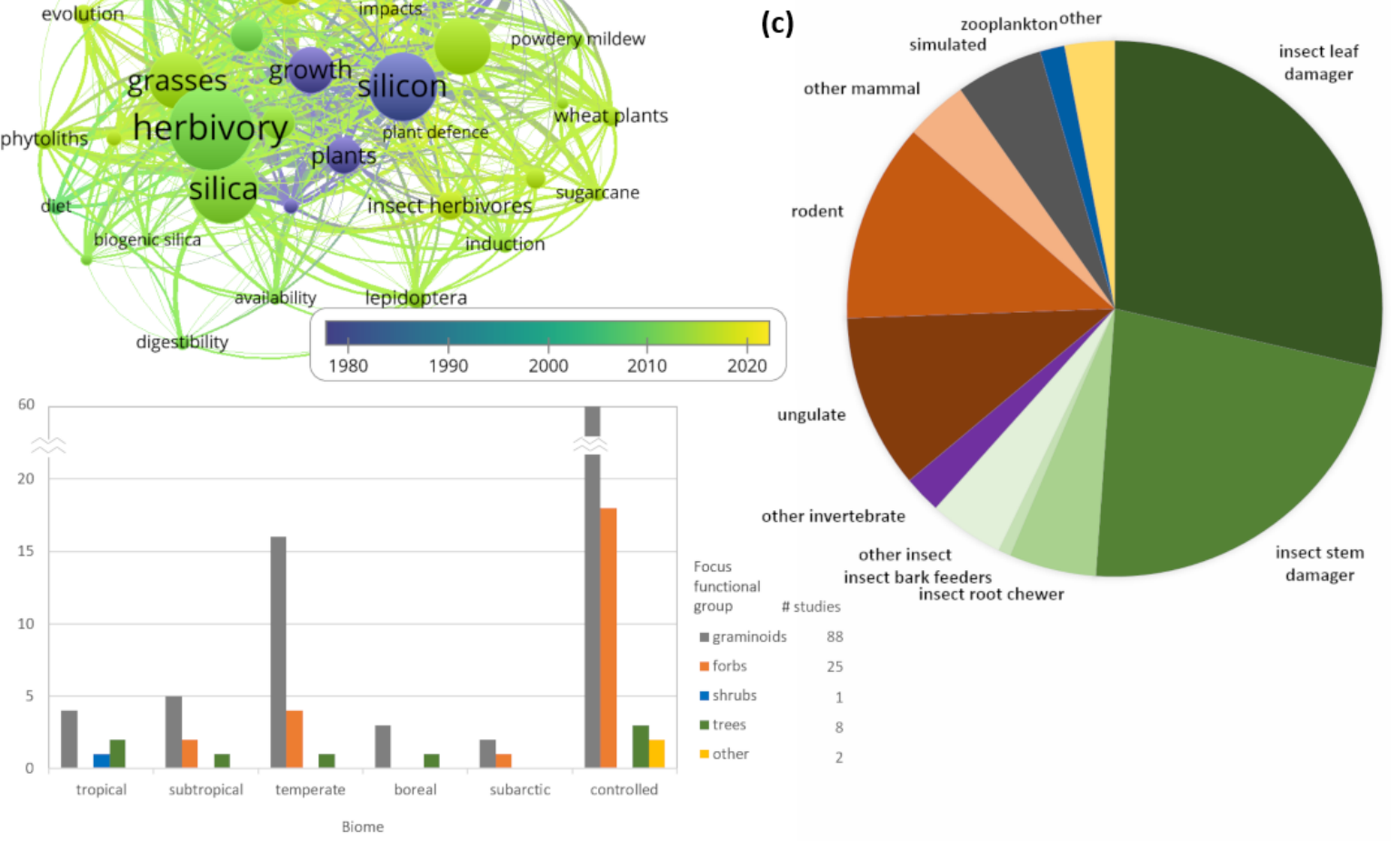

Figure 1. Summary of literature review. (a) Network map of keywords from publications between 1900-2020 in the Web of Science core collection database generated using search terms "silic*" and "herbivor"" and not "in silico" (314 results). Bubble and word size is scaled to the total occurrence of the keywords in all publications (only > 10 occurrences displayed); more proximate bubbles/keywords co-occur more often in the publications surveyed. The year indicates the average publication year of the documents in which a keyword occurs. The map was created with VOSviewer software (van Eck and Waltman, 2018). (b) Number of publications investigating each plant functional type and biome using the three search terms. We filtered the 314 results until only those publications that directly studied Si and herbivory remained (119 publications). (c) Percentage distribution of herbivore types for all 119 studies that directly investigated silicon and herbivory. The list of data sources and classifications for Fig. 1 are archived at https://doi.org/10.6084/m9.figshare.12026997.

grasslands can, by extension, then affect biogeochemical cycles (Schaller et al., 2017). Changes in plant nutrient stoichiometry due to Si may have broad implications for other natural systems, where the (un)availability of essential nutrients can shape the productivity, composition, diversity, dynamics and interactions of plant, animal, and microbial populations (Vitousek, 2004). For example, P can be limiting in weathered tropical forest soils (Vitousek, 2004), so changes in P availability due to Si (Neu et al., 2017) can have concomitant effects on productivity. Furthermore, the recycling of Si within forests impacts continental Si cycling, especially in tropical forests which take up $\mathrm{Si}$ at a faster rate in terms of mass per unit ground area than other biomes, particularly in highly weathered soils (Alexandre et al., 1997; Cornelis and Delvaux, 2016; Schaller et al., 2018). Notably, unlike major plant nutrients for which foliar concentrations significantly decreased with increasing soil age, foliar Si concentrations continually increased with increasing soil age in two Australian soil chronosequences (de Tombeur et al., 2020). Returning phytoliths to topsoil can result in the slow release of $\mathrm{Si}$ that sustains the terrestrial cycle during ecosystem retrogression.

A summary of literature shows that studies of $\mathrm{Si}$-herbivore dynamics have focused on the ecology and physiology of $\mathrm{Si}$ in the grass family (Fig. 1), Poaceae, which includes many species that accumulate large amounts of $\mathrm{Si}$ in their tissues. Species richness can increase plant Si stocks via its positive relationship with biomass production but can have a negative effect on $\mathrm{Si}$ concentration in the aboveground biomass, which may influence processes such as decomposition, nutrient cycling and herbivory (Schaller et al., 2016). Some studies indicate Si content of plant litter may be positively correlated to decomposition rate (e.g., Schaller and Struyf, 2013). Because plant-stored Si releases Si into soils and sediments 
relatively rapidly, high $\mathrm{Si}$-accumulating plants like grasses can influence Si turnover rates in ecosystems by uptake, storage, and release of Si during plant decomposition (Schaller et al., 2016, and references therein).

However, several non-monocot angiosperms also store significant foliar Si (Hodson et al., 2005), and variation in foliar Si can play important roles such as in plant defense and metal toxicity reduction even for low-accumulators (Katz, 2014, and references therein). Si contents vary by as much as 2-3 orders of magnitude among plant families, orders and phyla (Hodson et al., 2005), and grass-rich systems tend to be richer in Si and more productive than systems without grasses (Carey and Fulweiler, 2012). However, nutrient use strategies can vary intra-specifically across environmental gradients at least within controlled settings (Harley and DeGabriel, 2016, and references therein).

Anthropogenic perturbations, such as agriculture, deforestation, urbanization, and climate warming, can also have profound effects on terrestrial silica biogeochemistry (Conley et al., 2008; Struyf and Conley, 2012; Carey and Fulweiler, 2016; Gewirtzman et al., 2019). Deforested areas can increase soil erosion, resulting in the loss of high biogenic Si concentrations found in surface soils (Saccone et al., 2007). Urban areas have limited ability to take up dissolved $\mathrm{Si}$ into vegetation, and agricultural lands retain less biogenic $\mathrm{Si}$ as it is frequently removed through harvesting and may not be replenished by vegetation-stimulated silicate weathering (Struyf and Conley, 2012; Vandevenne et al., 2012). Global agricultural Si export from harvesting is estimated to be $223 \mathrm{~kg} \mathrm{Si} \mathrm{yr}^{-1}$ (Matichenkov and Bocharnikova, 2001) compared to the $142 \mathrm{~kg} \mathrm{Si} \mathrm{yr}^{-1}$ total quantity of dissolved Si transferred from continents to oceans by rivers (Tréguer et al., 1995). In addition, soil warming due to climate change can increase the extent of internal Si recycling in temperate forests (Gewirtzman et al., 2019), and changes in precipitation intensity, as expected with climate change, can increase surface run-off and top-soil erosion-reducing biogenic $\mathrm{Si}$ in surface soils (Conley et al., 2008; Struyf et al., 2010).

\section{Effects of silicon on herbivory}

$\mathrm{Si}$ is known to defend plants against a wide range of biotic stresses, including pathogen infection and herbivory (Reynolds et al., 2009; Guntzer et al., 2012; Frew et al., 2018, and references therein). Si-mediated defenses against herbivores involve both direct and indirect physical or mechanical barriers, as well as indirect biochemical or molecular mechanisms (Fig. 2). In addition, plant communities with high Si can affect herbivore communities. Plant groups with high leaf toughness, high $\mathrm{Si}$ concentrations, and low leaf $\mathrm{N}$ concentrations, for example, can also be associated with decreased grassland herbivore species richness (Schuldt et al., 2019). Furthermore, studies have reported how grass Si content can drive herbivore populations, which may be synchro-

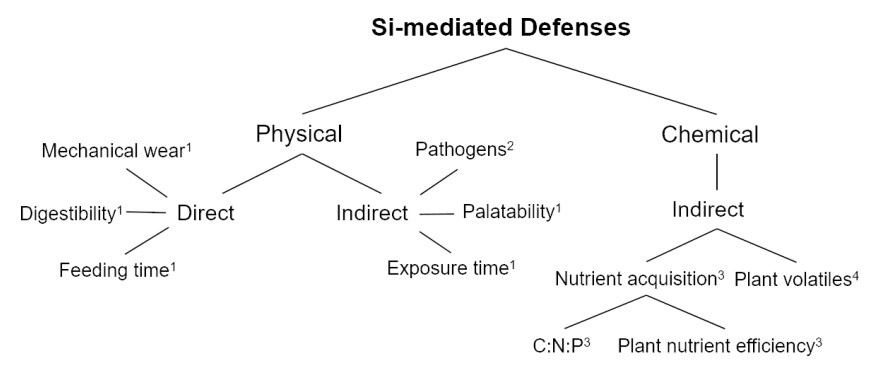

Figure 2. Direct and indirect physical and chemical plant Simediated defenses to herbivory. ${ }^{1}$ Massey and Hartley (2009) and references therein. ${ }^{2}$ Lev-Yadun and Halpern (2019). ${ }^{3}$ Neu et al. (2017). ${ }^{4}$ Liu et al. (2017).

nized with plant Si content cycles (Massey et al., 2008; Hartley, 2015).

Si-derived mechanical barriers are often thought to effectively shorten the duration of attack, both directly or indirectly, by making tissues more difficult to chew, penetrate, and digest (Hunt et al., 2008; Massey and Hartley, 2009), and increasing exposure time to predators (Massey and Hartley, 2009). For example, discrete silica bodies in and on the surface of leaves can reduce herbivory (Hartley et al., 2015). Si structures may wear down herbivore mouthparts (Massey and Hartley, 2009), affecting herbivore ingestion and nutrition (Frew et al., 2018; Hunt et al., 2008). These abrasive phytoliths can also lacerate herbivore body parts or facilitate pathogen transmission into herbivores (Lev-Yadun and Halpern, 2019). Si may also alter nutritional quality indirectly via changes to the foliar $\mathrm{C}: \mathrm{N}$ ratio and $\mathrm{P}$ concentrations (Frew et al., 2018) while plant nutrient status may influence the overall efficacy of Si-based defenses against herbivory (Moise et al., 2019). As a consequence, some herbivores demonstrate a low preference for Si-rich plants and slower growth rates when feeding on Si-rich diets (Massey and Hartley, 2006, 2009).

Several studies have documented the effects of soil $\mathrm{Si}$ addition on plant chemical defenses (e.g., Reynolds et al., 2009), anti-herbivore phytohormonal signaling (e.g., Hall et al., 2019), and changes in plant nutritional quality (e.g., Frew et al., 2018; Moise et al., 2019). For example, Si may induce indirect defense mechanisms by altering the composition of herbivore-induced plant volatiles that attract herbivore parasitoids and predators (Liu et al., 2017). Some studies also point to effects of Si on plant secondary metabolism and gene expression in plant development and defense (Markovich et al., 2017; Frew et al., 2018, and references therein). But because Si has relatively limited chemical reactivity, its role in plant chemical changes may be indirect rather than direct (Coskun et al., 2019). For example, effectors released by insects could be trapped within the extracellular Si matrix, precluding them from deregulating the plant defense response, or from recognizing the plant as a suitable host (Coskun et al., 2019). 
While researchers continue to debate the biological roles of $\mathrm{Si}$ and uncover the mechanisms behind them (Frew et al., 2018; Coskun et al., 2019), we conclude that, at a minimum, Si mitigates the negative impacts of various stressors, such as herbivory, which then enable plants to improve growth potential (Johnson et al., 2019).

\section{Effects of herbivory on plant silicon}

Of the 119 reviewed studies, the majority of $\mathrm{Si}$-herbivory publications have focused on insects that damage shoots (68), while other animals including mammals (35) and insects from other feeding guilds (14) are less frequently represented (Fig. 1). While many studies in the literature review investigate the effects of Si on herbivory (114), few studies focus on the effects of herbivory on Si (5). Though few, these studies show that herbivores can also induce Si uptake and accumulation by plants in response to herbivore attack (Massey et al., 2007; Hartley and DeGabriel, 2016). Although how much Si uptake is induced may depend on plant species, herbivore type, and environmental conditions, the degree of induction can be positively correlated with herbivory duration or frequency (Soininen et al., 2013). In one study, the Si content of two species of grasses that experienced repeated damage by voles and locusts was 2-4 times more than individuals of the same species that experienced only one damage event (Massey et al., 2007). Some grass species have been shown to have as much as twice the Si contents in more heavily grazed localities (Brizuela et al., 1986). However, one study investigating grazing effects on Si yielded different results. In a salt marsh, $\mathrm{Si}$ export rates at sheep-grazed sites were actually lower than at ungrazed sites (Müller et al., 2013). Variable responses between different grasslands underscore the need for wider sampling to study $\mathrm{Si}$-herbivory dynamics in different ecosystems with their unique characteristics.

\section{Potential effects of herbivory on terrestrial silicon cycling}

While multiple reviews synthesize terrestrial Si biogeochemical cycling (e.g., Conley, 2002; Struyf and Conley, 2012) and effects of Si on herbivory (e.g., Debona et al., 2017; Frew et al., 2018), few studies have explored the potential effects of herbivory on Si cycling. Variation in Si accumulation and deposition associated with herbivory, Si availability, and environmental variables could have important implications for Si cycling (Cooke and DeGabriel, 2016, and references therein). Herbivores can distribute large quantities of resources across the landscape, having important effects on nutrient cycling and ecosystem productivity (Metcalfe et al., 2014; Bakker et al., 2016). Schoelynck et al. (2019), for example, found that hippos contribute $32 \%$ to the biogenic Si flux and more than $76 \%$ to the total Si flux in a savannah-river system. Bringing together published Si flux data with estimates of herbivory for the first time, we estimate that Si fluxes via the herbivory pathway could meet or exceed other major sources of Si (Table 1), although flux information on some major habitat types is missing. Herbivores may also influence $\mathrm{Si}$ pathways by making more labile forms of $\mathrm{Si}$ available. For example, Vandevenne et al. (2013) found that grazing by cattle can increase the reactivity and dissolvability of biogenic Si after digestion, leading to higher Si turnover rates and mobilization potential (2 versus $20 \mathrm{~kg} \mathrm{Si} \mathrm{ha}^{-1} \mathrm{yr}^{-1}$ ). Greater Si mobilization terrestrially due to herbivory can potentially affect the uptake of $\mathrm{Si}$ by plants as well as the movement of other linked nutrients indirectly (Fig. 3). It is, however, currently unclear whether the more mobilized $\mathrm{Si}$ is absorbed by vegetation, taken up by microbes, or exported from the system. Future research could follow the fate of more mobilized Si derived from herbivores, which may depend on local biotic and abiotic conditions such as soil properties or plant/microbial composition. In a wetland study, litter decomposition by heterotrophic microbes was significantly influenced by the Si availability during plant growth, whereby litter decomposition rates were positively correlated with higher Si content (Schaller and Struyf, 2013). In other words, potentially greater export and plant uptake of biogenic Si due to herbivory may impact decomposition and nutrient cycling in some systems. Grasslands demonstrate a high capacity to store biogenic $\mathrm{Si}$ as well as transport Si from relatively inert mineral silicate soil layers to biologically active soil layers (Blecker et al., 2006). If grazing can change the distribution and reactivity of $\mathrm{Si}$ in grasslands, herbivory may alter Si turnover and export at rates important to estimate for Si cycling in other agricultural and natural systems as well. Understanding the role of herbivores in mobilizing Si may have important implications for land management.

Researchers have found that even small shifts in terrestrial biogenic Si reactivity could alter the balance between Si storage and export from ecosystems (Struyf and Conley, 2012). Herbivory may increase dissolved Si mobility (Vandevenne et al., 2013) and, if absorbed by plants, thereby decrease $\mathrm{C}$ uptake (Cooke and Leishman, 2012), increase $\mathrm{N}$ use efficiency, and increase P uptake of plants (Neu et al., 2017; also see Fig. 3). Grassland herbivores may also preferentially consume plants with less Si (Massey and Hartley, 2006), potentially influencing ecosystem Si cycling and plant community dynamics (Garbuzov et al., 2011). Combined with Simediated changes in plant nutrient stoichiometry and efficiency (Neu et al., 2017), these findings highlight the need for more field research on how herbivory-Si interactions impact community- and ecosystem-level processes.

\section{Conclusions}

Our analysis has shown the magnitude of the impact of plant $\mathrm{Si}$ on herbivore populations and the potential impact of her- 
(a)

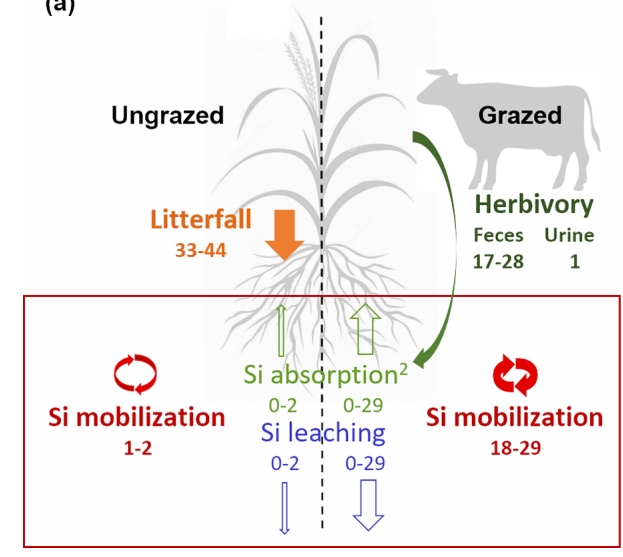

(b)

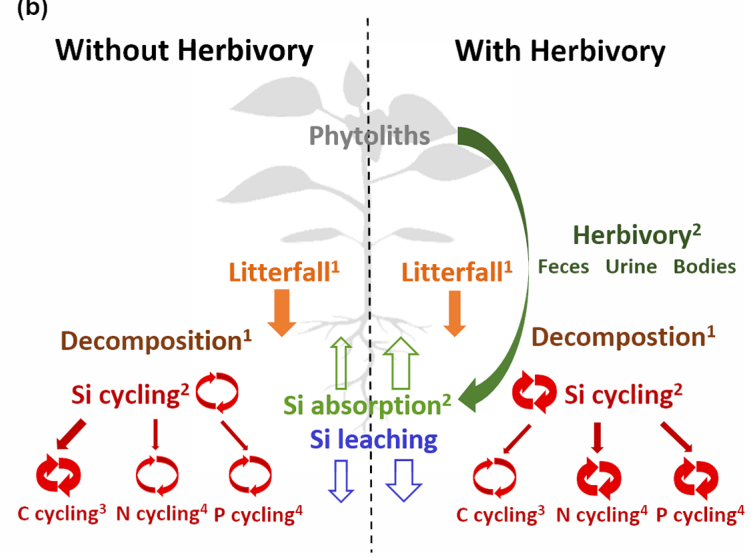

Figure 3. (a) Schematic of Si fluxes $\left(\mathrm{kg} \mathrm{ha}^{-1} \mathrm{yr}^{-1}\right)$ in hypothetical ungrazed and grazed grassland, dominated by cows, adapted from Vandevenne et al. (2013). Annual net primary production is assumed to be the same for both systems $\left(11000 \mathrm{~kg} \mathrm{ha}^{-1} \mathrm{yr}^{-1}\right)$, and all biomass is converted to litter or consumed by grazers in the grazed system. A biomass conversion ratio of $1: 4$ for grass versus feces is suggested for all herbivores. Mobilization percentages for faeces are based on ranges (minimum-maximum values) obtained in a dissolution experiment by Vandevenne et al. (2013) after $24 \mathrm{~h}$ in rain water; for urine, a conservative estimation of $3 \%$ mobilization was used. (b) Schematic of potential nutrient cycle differences in the plant-soil system with and without herbivory. Size of arrows denotes the size of the flux relative to the alternative scenario. ${ }^{1}$ Schaller et al. (2016). ${ }^{2}$ Brizuela et al. (1986). ${ }^{3}$ Street-Perrott and Barker (2008). ${ }^{4}$ Neu et al. (2017), Schaller et al. (2017).

Table 1. Estimated Si fluxes by atmosphere, mineral weathering and herbivory by major terrestrial habitat type. ANPP is aboveground net primary productivity.

\begin{tabular}{|c|c|c|c|c|c|c|c|}
\hline Habitat type ${ }^{a}$ & $\begin{array}{l}\text { Herbivory }^{a} \\
(\% \text { ANPP) }\end{array}$ & $\begin{array}{r}\mathrm{ANPP}^{\mathrm{a}} \\
\left(\mathrm{g} \mathrm{C} \mathrm{m}^{-2} \mathrm{yr}^{-1}\right)\end{array}$ & $\begin{array}{r}\text { \% Si by dry } \\
\text { weight }^{\mathrm{b}, \mathrm{c}}\end{array}$ & $\mathrm{Si}: \mathrm{C}^{\mathrm{c}}$ & $\begin{array}{r}\text { Herbivory } \\
\left(\mathrm{g} \mathrm{Si} \mathrm{m}^{-2} \mathrm{yr}^{-1}\right)\end{array}$ & $\begin{array}{l}\text { Atmospheric } \\
\left(\mathrm{g} \mathrm{Si} \mathrm{m}^{-2} \mathrm{yr}^{-1}\right)\end{array}$ & $\begin{array}{r}\text { Weathering } \\
\left(\mathrm{g} \mathrm{Si} \mathrm{m}^{-2} \mathrm{yr}^{-1}\right)\end{array}$ \\
\hline $\begin{array}{l}\text { Tundra shrublands } \\
\text { and grasslands }\end{array}$ & $1.8 \pm 0.6$ & $95.3 \pm 31.0$ & 1.07 & 0.02 & 0.04 & - & - \\
\hline $\begin{array}{l}\text { Temperate/tropical } \\
\text { shrublands and forests }\end{array}$ & $7.9 \pm 1.5$ & $334.6 \pm 24.9$ & 0.26 & 0.01 & 0.15 & $0.0040-0.2$ & $0.3-3.2$ \\
\hline $\begin{array}{l}\text { Temperate/tropical } \\
\text { grasslands }\end{array}$ & $34.1 \pm 5.3$ & $239.4 \pm 34.0$ & 1.33 & 0.03 & 2.31 & 0.2 & $0.4 \pm 2.5$ \\
\hline $\begin{array}{l}\text { Freshwater and } \\
\text { marine marshes }\end{array}$ & $16.8 \pm 5.0$ & $958.9 \pm 179.0$ & 0.62 & 0.01 & 2.13 & - & - \\
\hline Mangroves & $3.5 \pm 0.5$ & $500^{\mathrm{e}}$ & $0.43^{\mathrm{f}}$ & 0.01 & 1.60 & - & - \\
\hline
\end{tabular}

${ }^{\mathrm{a}}$ Cebrian (2004). ${ }^{\mathrm{b}}$ Hodson et al. (2005). ${ }^{\mathrm{c}}$ As calculated by Carey and Fulweiler (2012). ${ }^{\mathrm{d}}$ Street-Perrott and Barker (2008) and references therein. ${ }^{\mathrm{e}}$ Modeled by Ribeiro et al. (2019). ${ }^{\mathrm{f}}$ Ariyanto et al. (2019).

bivores on Si fluxes, which may have important agricultural and land management implications. In an effort to improve land management decisions and projections of biogeochemical cycling to future climate and land-use changes, however, we need to expand our understanding of Si-herbivore dynamics. Long-standing research makes it clear that Si plays an important role in both biogeochemistry cycling and herbivory, but major knowledge gaps remain. Based upon our review we highlight the following future research priorities:

- fate of more mobilized Si as a result of herbivory in agricultural settings;
- how Si-herbivory dynamics operate beyond crops in controlled or agricultural settings;

- Si-herbivore dynamics in herbivore feeding guilds other than shoot feeders;

- impact of herbivory on biogeochemical cycling in natural settings, which remain understudied but where evidence indicates that $\mathrm{Si}$ can cycle at a high rate and herbivory is an important ecosystem process;

- field-based studies on Si-herbivory dynamics along key environmental gradients by different herbivore feeding guilds. 
Given the demonstrated importance of $\mathrm{Si}$ and herbivores, and the relative paucity of information on their interaction particularly in natural, non-graminoid dominated systems, we believe this information is critical to generating more accurate model representations of animal-plant-soil feedbacks, and their impacts upon ecosystem processes in different terrestrial systems.

Data availability. The list of publications reviewed and classified for this article can be found at https://doi.org/10.6084/m9.figshare. 12026997 (Hwang and Metcalfe, 2020).

Author contributions. $\mathrm{BCH}$ and DBM conceived the ideas and designed methodology; $\mathrm{BCH}$ collected and synthesized the data. With input from DBM, BCH led the writing of the paper. Both authors contributed critically to the drafts and gave final approval for publication.

Competing interests. The authors declare that they have no conflict of interest.

Acknowledgements. We thank Daniel Conley for helpful comments on an early version of the paper.

Financial support. This research has been supported by the European Research Council, H2020 European Research Council (ECOHERB, grant no. 682707).

Review statement. This paper was edited by Sara Vicca and reviewed by Jonas Schoelynck and one anonymous referee.

\section{References}

Alexandre, A., Meunier, J.-D., Lézine A.-M., Vincens, A., and Schwartz, D.: Phytoliths: indicators of grassland dynamics during the late Holocene in intertropical Africa, Palaeogeogr. Palaeocl., 136, 213-229, https://doi.org/10.1016/s00310182(97)00089-8, 1997

Ariyanto, D., Gunawan, H., Puspitasari, D., Ningsih, S. S., Jayanegara, A., and Hamim, H.: The differences in element content in Rhizophora Mucronata leaves from Asahan Regency North Sumatra, Indonesia, Pol. J. Natur. Sc., 34, 481-491, 2019.

Bakker, E. S., Pages, J. F., Arthur, R., and Alcoverro, T.: Assessing the role of large herbivores in the structuring and functioning of freshwater and marine angiosperm ecosystems, Ecography, 39, 162-179, https://doi.org/10.1111/ecog.01651, 2016.

Bardgett, R. D. and Wardle, D. A.: Herbivore-Mediated Linkages between Aboveground and Belowground Communities, Ecology, 84, 2258-2268, https://doi.org/10.1890/02-0274, 2003.

Blecker, S. W., McCulley, R. L., Chadwick, O. A., and Kelly, E. F.: Biologic cycling of silica across a grass- land bioclimosequence, Global Biogeochem. Cy., 20, GB3023, https://doi.org/10.1029/2006gb002690, 2006.

Brackhage, C., Schaller, J., Bäucker, E., and Dudel, E. G.: Silicon availability affects the stoichiometry and content of calcium and micro nutrients in the leaves of Common Reed, Silicon, 5, 199 204, https://doi.org/10.1007/s12633-013-9145-3, 2013.

Brizuela, M. A., Detling, J. K., and Cid, M, S.: Silicon concentration of grasses growing in sites with different grazing histories, Ecology, 67, 1098-1101, https://doi.org/10.2307/1939834, 1986.

Carey, J. C. and Fulweiler, R. W.: The Terrestrial Silica Pump, Plos One, 7, e52932, https://doi.org/10.1371/journal.pone.0052932, 2012.

Carey, J. C. and Fulweiler, R. W.: Human appropriation of biogenic silicon - the increasing role of agriculture, Funct. Ecol., 30, 1331-1339, https://doi.org/10.1111/1365-2435.12544, 2016.

Cebrian, J.: Role of first-order consumers in ecosystem carbon flow, Ecol. Lett., 7, 232-240, https://doi.org/10.1111/j.14610248.2004.00574.x, 2004.

Conley, D. J.: Terrestrial ecosystems and the global biogeochemical silica cycle, Global Biogeochem. Cy., 16, 68-1-68-8, https://doi.org/10.1029/2002gb001894, 2002.

Conley, D. J., Likens, G. E., Buso, D. C., Saccone, L., Bailey, S. W., and Johnson, C. E.: Deforestation causes increased dissolved silicate losses in the Hubbard Brook Experimental Forest, Glob. Change Biol., 14, 2548-2554, https://doi.org/10.1111/j.13652486.2008.01667.x, 2008.

Cooke, J. and Leishman, M. R.: Is plant ecology more siliceous than we realize?, Trends Plant Sci., 16, 61-68, https://doi.org/10.1016/j.tplants.2010.10.003, 2011.

Cooke, J. and Leishman, M. R.: Tradeoffs between foliar and carbon-based defences: evidence from vegetation communities of contrasting soil types, Oikos, 121, 2052-2060, https://doi.org/10.1111/j.1600-0706.2012.20057.x, 2012.

Cooke, J. and DeGabriel, J. L.: Editorial: Plant Silicon Interactions between Organisms and the Implications for Ecosystems, Front Plant Sci., 7, 1001, https://doi.org/10.3389/fpls.2016.01001, 2016.

Cooke, J., DeGabriel, J. L., and Hartley, S. E.: The functional ecology of plant silicon: geoscience to genes, Funct. Ecol., 30, 12701276, https://doi.org/10.1111/1365-2435.12711, 2016.

Cornelis, J. T. and Delvaux, B.: Soil processes drive the biological silicon feedback loop, Funct. Ecol., 30, 1298-1310, https://doi.org/10.1111/1365-2435.12704, 2016.

Cornelis, J., Ranger, J., Iserentant, A., and Delvaux, B.: Tree species impact the terrestrial cycle of silicon through various uptakes, Biogeochemistry, 97, 231-245, https://doi.org/10.1007/s10533009-9369-x, 2010.

Coskun, D., Deshmukh, R., Sonah, H., Menzies, J. G., Reynolds, O. L., Ma, J. F., Kronzucker, H. J., and Bélanger, R. R.: The controversies of silicon's role in plant biology, New Phytol., 221, 67-85, https://doi.org/10.1111/nph.15343, 2019.

De Tombeur, F., Turner, B. L., Laliberte, E., Lambers, H., Mahy, G., Faucon, M.-P., Zeminuk, H., and Cornelis, J. T.: Plants sustain the terrestrial silicon cycle during ecosystem retrogression, Science, 369, 1245-1248, https://doi.org/10.1126/science.abc0393, 2020.

Debona, D., Rodrigues, F. A., and Datnoff, L. E.: Silicon's role in abiotic and biotic plant stresses, Annu. Rev. Phytopathol., 55, 
85-107, https://doi.org/10.1146/annurev-phyto-080516-035312, 2017.

Derry, L. A., Kurtz, A. C., Ziegler, K., and Chadwick, O. A.: Biological control of terrestrial silica cycling and export fluxes to watersheds, Nature, 433, 728-731, https://doi.org/10.1038/nature03299, 2005.

Drever, J. I.: The effect of land plants on weathering rates of silicate minerals, Geochim. Cosmochim. Ac., 58, 2325-2332, https://doi.org/10.1016/0016-7037(94)90013-2, 1994.

Elser, J. J., Bracken, M. E. S., Cleland, E. E., Gruner, D. S., Harpole, W. S., Hillebrand, H., Ngai, J. T., Seabloom, E. W., Shurin J. B., and Smith, J. E.: Global analysis of nitrogen and phosphorus limitation of primary producers in freshwater, marine and terrestrial ecosystems, Ecol. Lett., 10, 1135-1142, https://doi.org/10.1111/j.1461-0248.2007.01113.x, 2007.

Epstein, E.: Silicon, Annu. Rev. Plant Phys., 50, 641-664, https://doi.org/10.1146/annurev.arplant.50.1.641, 1999.

Frew, A., Weston, L. A., Reynolds, O. L., and Gurr, G. M.: The role of silicon in plant biology: a paradigm shift in research approach, Ann. Bot., 121, 1265-1273, https://doi.org/10.1093/aob/mcy009, 2018.

Garbuzov, M., Reidinger, S., and Hartley, S.: Interactive effects of plant-available soil silicon and herbivory on competition between two grass species, Ann. Bot., 108, 1355-1363, https://doi.org/10.1093/aob/mcr230, 2011.

Gewirtzman, J., Tang, J., Melillo, J. M., Werner, W. J., Kurtz, A. C., Fulweiler, R. W., and Carey, J. C.: Soil Warming Accelerates Biogeochemical Silica Cycling in a Temperate Forest, Front. Plant Sci., 10, 1097, https://doi.org/10.3389/fpls.2019.01097, 2019.

Guntzer, F., Keller, C., and Meunier, J. D.: Benefits of plant silicon for crops: a review, Agron. Sustain. Dev., 32, 201-213, https://doi.org/10.1007/s13593-011-0039-8, 2012.

Hall, C. R., Waterman J. M., Vandegeer, R. K., Hartley, S. E., and Johnson, S. N.: The Role of Silicon in Antiherbivore Phytohormonal Signalling, Front. Plant Sci., 10, 1132, https://doi.org/10.3389/fpls.2019.01132, 2019.

Hartley, S. E.: Round and round in cycles? Silicon-based plant defences and vole population dynamics, Funct. Ecol., 29, 151-153, https://doi.org/10.1111/1365-2435.12365, 2015.

Hartley, S. E. and DeGabriel, J. L.: The ecology of herbivoreinduced silicon defences in grasses, Funct. Ecol., 30, 1311-1322, https://doi.org/10.1111/1365-2435.12706, 2016.

Hartley, S. E. and Jones, T. H.: Insect herbivores, nutrient cycling and plant productivity, in: Insects and ecosystem function, edited by: Weisser, W. W. and Siemann, E., Springer-Verlag, Heidelberg, Germany, 27-46, https://doi.org/10.1007/978-3-54074004-9_2, 2004.

Hartley, S. E., Fitt, R. N., McLarnon, E. L., and Wade, R. N.: Defending the leaf surface: intra- and inter-specific differences in silicon deposition in grasses in response to damage and silicon supply, Front. Plant Sci., 6, 35, https://doi.org/10.3389/fpls.2015.00035, 2015.

Hodson, M. J., White, P. J., Mead, A., and Broadley, M. R.: Phylogenetic variation in the silicon composition of plants, Ann. Bot., 96, 1027-1046, https://doi.org/10.1093/aob/mci255, 2005.

Hunt, J. W., Dean, A. P., Webster, R. E., Johnson, G. N., and Ennos, A. R.: A novel mechanism by which silica de- fends grasses against herbivory, Ann. Bot., 102, 653-656, https://doi.org/10.1093/aob/mcn130, 2008.

Hwang, B. and Metcalfe, D. B.: SiHerbMiniArchive.xlsx, figshare, https://doi.org/10.6084/m9.figshare.12026997, 2020.

Johnson, S. N., Rowe R. C., and Hall, C. R.: Silicon is an inducible and effective herbivore defence against Helicoverpa punctigera (Lepidoptera: Noctuidae) in soybean, B. Entomol. Res., 110, 417-422, https://doi.org/10.1017/s0007485319000798, 2019.

Katz, O.: Beyond grasses: the potential benefits of studying silicon accumulation in non-grass species, Front. Plant Sci., 5, 376, https://doi.org/10.3389/fpls.2014.00376, 2014.

Katz, O.: Silicon content is a plant functional trait: implications in a changing world, Flora, 254, 88-94, https://doi.org/10.1016/j.flora.2018.08.007, 2019.

Kristensen, J. A., Metcalfe, D. B., and Rousk, J.: The biogeochemical consequences of litter transformation by insect herbivory in the subarctic: a microcosm simulation experiment, Biogeochemistry, 138, 323-336, https://doi.org/10.1007/s10533-018-0448-8, 2018.

Lev-Yadun, S. and Halpern, M.: Extended phenotype in action. Two possible roles for silica needles in plants: not just injuring herbivores but also inserting pathogens into their tissues, Plant Signaling and Behavior, 14, 7, https://doi.org/10.1080/15592324.2019.1609858, 2019.

Liu, J., Zhu, J., Zhang, P., Han, L., Reynolds, O. L., Zeng, R., Wu, J., Shao, Y., You, M., and Gurr, G. M.: Silicon Supplementation Alters the Composition of Herbivore Induced Plant Volatiles and Enhances Attraction of Parasitoids to Infested Rice Plants, Front. Plant Sci., 8, 1265, https://doi.org/10.3389/fpls.2017.01265, 2017.

Markovich, O., Steiner, E., Kouřil, Š., Tarkowski, P., Aharoni, A., and Elbaum, R.: Silicon promotes cytokinin biosynthesis and delays senescence in Arabidopsis and Sorghum, Plant Cell Environ., 40, 1189-1196, https://doi.org/10.1111/pce.12913, 2017.

Massey, F. P. and Hartley, S. E.: Experimental demonstration of the antiherbivore effects of silica in grasses: impacts on foliage digestibility and vole growth rates, P. Roy. Soc. Lond. B Bio., 273, 2299-2304, https://doi.org/10.1098/rspb.2006.3586, 2006.

Massey, F. P. and Hartley, S. E.: Physical defences wear you down: progressive and irreversible impacts of silica on insect herbivores, J. Anim. Ecol., 78, 281-291, https://doi.org/10.1111/j.1365-2656.2008.01472.x, 2009.

Massey, F. P., Ennos, A. R., and Hartley, S. E.: Herbivore specific induction of silica-based plant defences, Oecologia, 152, 677683, https://10.1007/s00442-007-0703-5, 2007.

Massey, F. P., Smith, M. J., Lambin, X., and Hartley, S. E.: Are silica defences in grasses driving vole population cycles?, Biol. Lett., 4, 419-422, https://doi.org/10.1098/rsbl.2008.0106, 2008.

Matichenkov, V. V. and Bocharnikova, E. A.: The relationship between silica and soil physical and chemical properties, in: Silica in agriculture, edited by: Datnoff, L. E., Snyder, G. H., and Korndörfer, G. H., Elsevier, Amsterdam, Netherlands, https://doi.org/10.1016/S0928-3420(01)80017-3, 2001.

McNaughton S. J., Tarrants, J. L., McNaughton, M. M., and Davis, R. H.: Silica as a defense against herbivory and a growth promoter in African grasses, Ecology, 66, 528-535, https://doi.org/10.2307/1940401, 1985.

Metcalfe, D. B., Asner, G. P., Martin, R. E., Silva Espejo, J. E., Huasco, W. H., Farfán Amézquita, F. F., Javier E. Silva Espejo 
Walter Huaraca Huasco Felix F. Farfán Amézquita, CarranzaJimenez, L., Galiano Cabrera, D. F., Durand Baca, L., Sinca, F., Huaraca Quispe, L. P, Alzamora Taype, I., Eguiluz Mora, L., Rozas Dávila, A., Mamani Solórzano, M., Puma Vilca, B. L., Laupa Román, J. M., Guerra Bustios, P. C., Salinas Revilla, N., Tupayachi, R., Girardin, C. A. J., Doughty, C. E., and Yadvinder, M.: Herbivory makes major contributions to ecosystem carbon and nutrient cycling in tropical forests, Ecol. Lett., 17, 324-332, https://doi.org/10.1111/ele.12233, 2014.

Moise, E. R. D, McNeil, J. N., Hartley, S. E., and Henry, H. A. L.: Plant silicon effects on insect feeding dynamics are influenced by plant nitrogen availability, Entomol. Exp. Appl., 167, 91-97, https://doi.org/10.1111/eea.12750, 2019.

Müller, F., Struyf, E., Hartmann, J., Weiss, A., and Jensen, K. L.: Impact of grazing management on silica export dynamics of Wadden Sea saltmarshes, Estuar. Coast. Shelf Sci., 127, 1-11, https://doi.org/10.1016/j.ecss.2013.03.010, 2013.

Neu, S., Schaller, J., and Dudel, E. G.: Silicon availability modifies nutrient use efficiency and content, $\mathrm{C}: \mathrm{N}: \mathrm{P}$ stoichiometry, and productivity of winter wheat (Triticum aestivum L.), Sci. Rep.UK, 7, 40829, https://doi.org/10.1038/srep40829, 2017.

Parr, J. F. and Sullivan, L. A.: Soil carbon sequestration in phytoliths, Soil Biol. Biochem., 37, 117-124, https://doi.org/10.1016/j.soilbio.2004.06.013, 2005.

Ribeiro, R. D. A., Rovai, A. S., Twilley, R. R., and Castañeda-Moya, E.: Spatial variability of mangrove primary productivity in the neotropics, Ecosphere, 10, e02841, https://doi.org/10.1002/ecs2.2841, 2019.

Raven, J. A.: The transport and function of silicon in plants, Biol. Rev., 58, 179-207, https://doi.org/10.1111/j.1469185x.1983.tb00385.x, 1983.

Reynolds, O. L., Keeping, M. G., and Meyer, J. H.: Siliconaugmented resistance of plants to herbivorous insects: a review, Ann. Appl. Biol., 155, 171-186, https://doi.org/10.1111/j.17447348.2009.00348.x, 2009.

Saccone, L., Conley, D. J., Koning, E., Sauer, D., Sommer, M., Kaczorek, D., Blecker, S. W., and Kelly, E. F.: Assessing the extraction and quantification of amorphous silica in soils of forest and grassland ecosystems, Eur. J. Soil Sci., 58, 1446-1459, https://doi.org/10.1111/j.1365-2389.2007.00949.x, 2007.

Schaller, J. and Struyf, E.: Silicon controls microbial decay and nutrient release of grass litter during aquatic decomposition, Hydrobiologia, 709, 201-212, https://doi.org/10.1007/s10750-0131449-1, 2013.

Schaller, J., Brackhage, C., Gessner, M.O., Bäuker, E., and Dudel, E. G.: Silicon supply modifies C:N:P stoichiometry and growth of Phragmites australis, Plant Biol., 14, 392-396, https://doi.org/10.1111/j.1438-8677.2011.00537.x, 2012.

Schaller J., Roscher, C., Hillebrand, H., Weigelt, A., Oelmann, Y., Wilcke, W., Ebeling, A., and Weisser, W. W.: Plant diversity and functional groups affect $\mathrm{Si}$ and $\mathrm{Ca}$ pools in aboveground biomass of grassland systems, Oecologia, 182, 277-286, https://doi.org/10.1007/s00442-016-3647-9, 2016.

Schaller, J., Hodson, M. J., and Struyf, E.: Is relative Si/Ca availability crucial to the performance of grassland ecosystems?, Ecosphere, 8, e01726, https://doi.org/10.1002/ecs2.1726, 2017.

Schaller, J., Turner, B. L., Weissflog, A., Pino, D., Bielnicka, A. W., and Engelbrecht, B. M. J.: Silicon in tropical forests: large variation across soils and leaves suggests ecological significance,
Biogeochemistry, 140, 161-174, https://doi.org/10.1007/s10533018-0483-5, 2018.

Schaller, J., Faucherre, S., Joss, H., Obst, M., Goeckede, M., PlanerFriedrich, B. Peiffer, S., Gilfedder, B., and Elberling, B.: Silicon increases the phosphorus availability of Arctic soils, Sci. Rep.UK, 9, 449, https://doi.org/10.1038/s41598-018-37104-6, 2019.

Schoelynck, J., Bal, K., Backx, H., Okruszko, T., Meire, P., and Struyf, E.: Silica uptake in aquatic and wetland macrophytes: a strategic choice between silica, lignin and cellulose?, New Phytol., 186, 385-391, https://doi.org/10.1111/j.14698137.2009.03176.x, 2010.

Schoelynck, J., Müller, F., Vandevenne, F., Bal, K, Barão, L., Smis, A., Opdekamp, W., Meire, P., and Struyf, E.: Silicon-vegetation interaction in multiple ecosystems: a review, J. Veg. Sci., 25, 301-313, https://doi.org/10.1111/jvs.12055, 2014.

Schoelynck, J., Subalusky, A. L., Struyf, E., Dutton, C. L., Unzué-Belmonte, D., Van de Vijver, B., Post, D. M., Rosi, E. J., Meire, P., and Frings, P.: Hippos (Hippopotamus amphibius): The animal silicon pump, Sci. Adv., 5, eaav0395, https://doi.org/10.1126/sciadv.aav0395, 2019.

Schuldt, A., Ebeling, A., Kunz, M., Staab, M., GuimarãesSteinicke, C., Bachmann, D., Buchmann, N., Durka, W., Fichtner, A., Fornoff, F., Härdtle, W., Hertzog, L. R., Klein, A.M., Weisser, W., Wirth, C., Zhang, J., Bruelheide, H., and Eisenhauer, N.: Multiple plant diversity components drive consumer communities across ecosystems, Nat. Commun., 10, 1460, https://doi.org/10.1038/s41467-019-09448-8, 2019.

Soininen, E. M., Bråthen, K. A., Jusdado, J. G. H., Reidinger, S., and Hartley, S. E.: More than herbivory: levels of silicabased defences in grasses vary with plant species, genotype and location, Oikos, 122, 30-41, https://doi.org/10.1111/j.16000706.2012.20689.x, 2013.

Street-Perrott, F. A. and Barker, P. A.: Biogenic silica: a neglected component of the coupled global continental biogeochemical cycles of carbon and silicon, Earth Surf. Proc. Land., 33, 14361457, https://doi-org.ludwig.lub.lu.se/10.1002/esp.1712, 2008.

Struyf, E. and Conley, D.: Emerging understanding of the ecosystem silica filter, Biogeochemistry, 107, 9-18, https://doi.org/10.1007/s10533-011-9590-2, 2012.

Struyf, E., Smis, A., Van Damme, S., Garnier, J., Govers, G., Van Wesemael, B., Conley, D. J., Batelaan, O., Frot, E., Clymans, W., Vandevenne, F., Lancelot, C, Goos, P., and Meire, P.: Historical land use change has lowered terrestrial silica mobilization, Nat Commun., 1, 129, https://doi.org/10.1038/ncomms1128, 2010.

Tréguer, P. J. and De La Rocha, C. L.: The World Ocean Silica Cycle, Annu. Rev. Mar. Sci., 5, 477-501, https://doi.org/10.1146/annurev-marine-121211-172346, 2013.

Tréguer, P., Nelson, D. M., Bennekom, A. J. V., DeMaster, D. J., Leynaert, A., and Quéguiner, B.: The silica balance in the world ocean: a reestimate, Science, 268, 375-379, https://doi.org/10.1126/science.268.5209.375, 1995.

Van der Putten, W. H., Bardgett, R. D., Bever, J. D., Bezemer, T. M., Casper, B. B., Fukami, T., Kardol, P., Klironomos, J. N., Kulmatiski, A., Schweitzer, J. A., Suding, K. N., Van de Voorde, T. F. J., and Wardle, D. A.: Plant-soil feedbacks: the past, the present and future challenges, J. Ecol., 101, 265-276, https://doi.org/10.1111/1365-2745.12054, 2013.

van Eck, N. J. and Waltman, L.: VOSviewer manual, Version 1.6.8, Centre for Science and Technology Studies, Leiden, 
NL, Leiden University, available at: https://www.vosviewer. com/documentation/Manual_VOSviewer_1.6.8.pdf (last access: 1 February 2020), 2018.

Vandevenne, F., Barão, A. L., Schoelynck, J., Smis, A., Ryken, N., Van Damme, S., Meire, P., and Struyf, E.: Grazers: biocatalysts of terrestrial silica cycling, Proc. Biol. Sci., 280, 20132083, https://doi.org/10.1098/rspb.2013.2083, 2013.

Vandevenne, F., Struyf, E., Clymans, W., and Meire, P.: Agricultural silica harvest: have humans created a new loop in the global silica cycle?, Front. Ecol. Environ., 10, 243-248, https://doi.org/10.1890/110046, 2012.
Vitousek, P. M.: Nutrient Cycling and Limitation: Hawai'i as a Model System, Princeton University Press, Princeton, https://doi.org/10.1111/j.1442-9993.2005.01458.x, 2004. 